\title{
Ethnomedicinal Information and High-Performance Liquid Chromatography Analysis of Water Soluble Vitamins (C, B1, B3, B6, folic acid) and Fat Soluble Vitamins (A, D3, E) of Three Consumable Parts of Musa paradisiaca: Cultivated in Tripura, India
}

\author{
Bikash Debnath $^{(0)}$, Kuntal Manna* \\ Natural Cum Advance Synthetic Lab, Department of Pharmacy, Tripura Central University, Suryamaninagar, Agartala, India \\ E-mail: k_manna2002@yahoo.comy
}

Received: 12 August 2020; Revised: 19 April 2021; Accepted: 21 April 2021

\begin{abstract}
Musa paradisiaca (Banana plant), which belongs to Musaceae, is a tropical plant-based fruit crop for Tripura, India. The main consumable parts of the banana plant are fruit, stem, and flower. This study aims to analyze ethonomedicinal survey and determine the water-soluble (C, B1, B3, B6, folic acid) and fat-soluble (A, D3, E) vitamins of three consumable parts (unripe fruit, stem, and flower) of Musa paradisiaca, cultivated in Tripura, India. Ethnomedicinal information of plant samples were collected by field survey method. High-Performance Liquid Chromatography (HPLC) method was used for the determination of water-soluble (C, B1, B3, B6, folic acid) and fatsoluble (A, D3, E) vitamins. From ethnomedicinal survey it was observed that three edible parts of Musa paradisiaca to have medicinal values. The results revealed that banana fruit and banana stem contained an appreciated amount of water-soluble vitamins (C, B1, B3, B6, folic acid) compared to banana flowers. The content of vitamin C of banana fruit, banana stem, and the banana flower was $1.3 \pm 0.2 \mathrm{mg} / \mathrm{g}$ dry powder, $1.8 \pm 0.3 \mathrm{mg} / \mathrm{g}$ dry powder, and $0.7 \pm 0.2 \mathrm{mg} /$ $\mathrm{g}$ dry powder respectively. In fat-soluble vitamins, vitamin A was present in a fair amount of banana fruit (18.3 \pm 3.8 $\mathrm{mg} / \mathrm{g}$ dry powder), stem $(11.8 \pm 2.3 \mathrm{mg} / \mathrm{g}$ dry powder), and flower $(10.7 \pm 1.6 \mathrm{mg} / \mathrm{g}$ dry powder). Results suggested that frequent intake of the banana's consumable parts may minimize vitamin deficiency in the human body.
\end{abstract}

Keywords: Musa paradisiaca, ethnomedicinal information, water-soluble vitamins, fat-soluble vitamins, dietary supplement

\section{Introduction}

Plant-based foods (fruits, flowers, vegetables, legumes, grains, nuts, and seeds) can fulfill essential human nutrition worldwide [1]. Musa paradisiaca is an important plant-based fruit crop of Tripura, a state of northeast India. This tropical crop grows well in Tripura in a temperature range of $15^{\circ} \mathrm{C}-35^{\circ} \mathrm{C}$ with a relative humidity of $75-85 \%$. It is a herbaceous flowering edible plant belongs to the family of Musaceae [2]. The fruit, flower, and stem of Musa paradisiaca (Banana) are the most edible parts. These three consumable parts play a significant role in modifying and maintaining normal physiological function [3]. In Northeast India, flower, stem, and unripe fruit of banana are also

Copyright (C2021 Kuntal Manna, et al.

DOI: https://doi.org/10.37256/fse.212021580

This is an open-access article distributed under a CC BY license

(Creative Commons Attribution 4.0 International License)

https://creativecommons.org/licenses/by/4.0/ 
eaten as a cooked vegetable to maintain the deficiency of vitamin A and C in the body, and to retain shortage of iron [2]. All the edible parts of banana are good sources of carbohydrate and also contained verities of minerals composition [4]. Banana fruit, flower, and stem contain abundant potassium should help lower the risk of heart disease [5]. Edible parts of banana also included in various health-promoting bioactive phytochemicals such as alkaloid, phenol, flavonoid, tannin, etc. [6]. The content of dietary fiber is high in banana fruit and help to improve constipation. Unripe banana consists mostly of starch, and the starch turns into sugar (glucose, fructose, and sucrose). Traditionally, banana stem juice helps in flushing out toxins from the body and reducing excessive weight. In Ayurveda, banana stem juice is also useful for the treatment of fatty liver disease [7]. In an empty stomach, every day, the intake of a glass of banana stem juice prevents kidney stones from forming [8]. Banana flowers can treat different bacterial infections. Banana flowers have shown excellent wound healing properties [7]. Ethnomedicinal studies of plants species are important for their medicinal and toxicological confirmation. In developing countries of Asia, South American, and African countries where traditional medicinal knowledge exists, ethnomedicinal research approaches are commonly employed [9]. One of our researches (Debnath and Manna, 2019) has estimated the phytochemicals, proximate composition, and mineral profiles, including the antioxidant activity of three edible parts of Musa paradisiaca, cultivated in Tripura, India. In our research, we have concluded that banana fruit contained a high amount of energy $(261.31 \mathrm{kcal} / 100 \mathrm{~g})$ compared to stem $(176.88 \mathrm{kcal} / 100 \mathrm{~g})$ and flower $(93.4 \mathrm{kcal} / 100 \mathrm{~g})$ and all the edible parts gave better antioxidant activity [2]. The objective of the present study is to ethnomedicinal survey and analyze water-soluble (C, B1, B3, B6, folic acid) and fat-soluble (A, D3, E) vitamins of three edible parts of Musa paradisiaca cultivated in geographical reason of Tripura, Northeast India. The novelty of this work is the analysis of vitamin content of consumable parts of banana mainly cultivated in the geographical condition of Tripura, India is the first time. The geographical situation of Tripura is too much diverse because the Himalayan region surrounds this state. Ethnomedicinal data collections are another significance in this work.

\section{Material and methods}

\subsection{Ethnomedicinal data collection}

Ethnomedicinal information about three edible parts of Musa paradisiaca were collected from oral interviews with traditional healers of Tripura (west Tripura). All the interected people are at least forty years old [10]. The scientific names of collected plant specimens were identified with the help of Plant Taxonomist, Department of Botany, Tripura University (A Central University).

\subsection{Processing of the plants material}

Three consumable collected parts (flower, unripe fruit, and stem) of Musa paradisiaca were washed thoroughly with tap water, slashed into tiny pieces, and carefully air-dried (applied warm temperature, low humidity with an air current). The dried pieces were further processed for grinding and transferred through a sieve of mesh size 40 to produce a fine powder. This powder objects was filled in a sealed package and stored at room temperature for further experimentation [2].

\subsection{Determination of water-soluble vitamins}

\subsubsection{Determination of $B$ group vitamins}

Five grams of powder of three different samples were placed separately in $25 \mathrm{~mL}$ of $\mathrm{H}_{2} \mathrm{SO}_{4}(0.1 \mathrm{~N})$ solution and incubated for $37 \mathrm{~min}$ at $122^{\circ} \mathrm{C}$. Then, the contents of the three different samples were cooled and adjusted to $\mathrm{pH} 4.5$ with $2.5 \mathrm{M}$ sodium acetate, and $50 \mathrm{mg}$ Taka-diastase enzyme was added. The prepared solution was stored overnight at $25^{\circ} \mathrm{C}$. The mixture was then filtered through a Whatman filter paper No. 4 . The filtrate was diluted with $50 \mathrm{~mL}$ of double distilled water and filtered again through a micropore filter $(0.45 \mu \mathrm{m})$. Twenty microliters of the filtrate were injected into the HPLC system (Shimadzu LC 10AS) in the triplicate. Standard stock solutions for thiamine, riboflavin, niacin, pyridoxine, cobalamin, and folic acid were used for quantification of vitamin B content of the test sample accomplished 
by comparison.

Instrumental condition-Reversed phase chromatographic separation was achieved on a-(RP-) HPLC column ZORBAX Eclipse Plus C18 $(250 \times 4.6 \mathrm{~mm}$, Particle size $5 \mu \mathrm{m})$ through the isocratic delivery mobile phase (A/B 33/67; A: $\mathrm{MeOH}, \mathrm{B}: 0.023 \mathrm{M} \mathrm{H}_{3} \mathrm{PO}_{4}, \mathrm{pH}=3.54$ ) at a flow rate of $0.5 \mathrm{~mL} / \mathrm{min}$. Ultraviolet $(\mathrm{UV})$ absorbance was recorded at $270 \mathrm{~nm}$ at room temperature $[11,12]$. To determine the B group vitamins, the quality assurance (QA) and quality control (QC) for the HPLC were regulated by the method of Kucukkolbasi et al., (2013) with some modifications [13].

\subsubsection{Determination of ascorbic acid}

Five grams powder of three different samples was homogenized separately with the same volume of $0.3 \mathrm{M}$ metaphosphoric acid and 1.4 M acetic acid. The mixture of three different samples was transferred in centrifuge tubes and centrifuged at 10,000 rpm for $22 \mathrm{~min}$. The mixture was then filtered through a Whatman filter paper No. 4 and filtered again through a micropore filter $(0.45 \mu \mathrm{m})$. Twenty microliters of the filtrate were injected into the HPLC system (Shimadzu LC 10AS) in the triplicate. Standard stock solutions for L-ascorbic acid was used for quantification of vitamin $\mathrm{C}$ content of the test sample accomplished by comparison.

Instrumental condition-Chromatographic separation was achieved on an RP-HPLC column through isocratic delivery of a mobile phase (A/B 33/67; A: $0.1 \mathrm{M}$ potassium acetate, $\mathrm{pH}=4.9$, B: acetonitrile: water [50:50]) at a flow rate of $1 \mathrm{~mL} / \mathrm{min}$. UV absorbance was recorded at $246 \mathrm{~nm}$ at room temperature [11]. To determine the B group vitamins, the QA and QC for the HPLC were regulated by the method of Kucukkolbasi et al., (2013) with some modifications [13].

\subsubsection{Determination of fat-soluble vitamins}

Five grams powder of three different samples, $0.5 \mathrm{~g}$ of pyrogallic acid, $35 \mathrm{~mL}$ ethanol, and $15 \mathrm{~mL}(50 \%) \mathrm{KOH}$ were added, mixed well separately, and refluxed for $45 \mathrm{~min}$ using a water bath at $47 \pm 5^{\circ} \mathrm{C}$. The three different solutions were neutralizing by added double-distilled water which then was dehydrated using anhydrous sodium sulfate. Further, the sample solutions were concentrated to approximately $2-5 \mathrm{~mL}$ using a water bath $\left(47 \pm 5^{\circ} \mathrm{C}\right)$, diluted to $10 \mathrm{~mL}$ using methanol. Then, the sample solutions were filtered using a $0.45 \mu \mathrm{m}$ membrane and finally subjected to HPLC analysis. Standard stock solutions for vitamin A, D3, and E were used to quantify selected fat-soluble vitamins.

Instrumental condition-RP-HPLC analysis was performed with the HPLC system (Shimadzu LC 10AS), including a diode array detector. The column was made of stainless steel. Analysis of fat-soluble vitamins, the Agilent Eclipse XDB-C18 column was used $(5 \mu \mathrm{m}, 4.6 \times 150 \mathrm{~mm})$, the solvent was methanol, and UV detection was recorded at 318 $\mathrm{nm}$ for vitamin A, $262 \mathrm{~nm}$ for vitamin D3, and 292nm for vitamin E. Separation of all vitamins was based on isocratic elution and the solvent flow rate was maintained at $1 \mathrm{~mL} / \mathrm{min}$. Twenty microliters of extracted oil was directly injected into the HPLC column in triplicate $[11,14]$. To determine the B group vitamins, the QA and QC for the HPLC were regulated by the method of Kucukkolbasi et al., (2013) with some modifications [13].

\section{Statistical analysis}

The mean and standard deviation (SD) of the mean values of water-soluble and fat-soluble vitamins were determined using the statistical software package SPSS 16.0 (SPSS Inc.; Chicago, IL, USA).

\section{Results and discussion}

\subsection{Ethnomedicinal study}

From the field research, three consumable parts of Musa paradisiaca have been found to use by the healers for curing different diseases (Table 1). For herbal medicine development, ethnomedicinal studies of plant species are of great importance. These studies ensure the protection of cultural heritage [15]. In the present study, it was observed that three edible parts of Musa paradisiaca to have medicinal values (Table 1). 
Table 1. Ethnomedicinal use reports of plant samples

\begin{tabular}{|c|c|c|c|}
\hline Botanical name and family & Plant parts & Habitate & Ethnomedicinal use report \\
\hline $\begin{array}{l}\text { Musa paradisiaca } \\
\text { (Musaceae) }\end{array}$ & Unripe fruit & Cultivated & $\begin{array}{c}\text { Used in iron deficiency anemia, used in constipation, } \\
\text { use in vitamin A and C deficiency syndrome }\end{array}$ \\
\hline $\begin{array}{l}\text { Musa paradisiaca } \\
\text { (Musaceae) }\end{array}$ & Stem & Cultivated & $\begin{array}{l}\text { Used in iron deficiency anemia, hepatoprotective activity, } \\
\text { regulate cholesterol and blood pressure }\end{array}$ \\
\hline $\begin{array}{l}\text { Musa paradisiaca } \\
\text { (Musaceae) }\end{array}$ & Flower & Cultivated & $\begin{array}{l}\text { Used in iron deficiency anemia, } \\
\text { control diabetics, improves lactation }\end{array}$ \\
\hline
\end{tabular}

\subsection{Determination of water-soluble vitamins}

After a quantitative analysis of water-soluble vitamins (Table 2) of three consumable parts of banana, it was found that the right amount of vitamin $\mathrm{C}$ was present in three experimental parts. A little amount of vitamin B1 and vitamin B6 was found only in banana fruit and stem. Three edible parts of the banana contained a small amount of vitamin B3 and folic acid. Fruits and vegetables perform a vital role in human malnutrition, especially as sources of vitamin C, vitamin B1, vitamin B3, vitamin B6, vitamin B12, folic acid, minerals, and dietary fiber [16]. Intake of fruits and vegetables in a regular diet has to defend the body from degenerative diseases [17]. The human body utilizes vitamin $\mathrm{C}$ in several ways. Vitamin $\mathrm{C}$ is needed to for the human body to form collagen. The standard function of vitamin $\mathrm{C}$ is to build skin, tendons, ligaments, and blood vessels. Vitamin $\mathrm{C}$ also protects cartilage, bones, and teeth, to heal wounds, and to form scar tissue. It is a vital antioxidant that helps protect cancer by blocking the damage made by free radicals [18]. It is also used for the treatment of eye diseases [19]. It also helps control the nervous system by the synthesis of the amino acid, carnitine, and catecholamine [17]. In this experiment, we have observed that three edible parts of banana (Musa paradisiaca) contain a reasonable amount of vitamin C (Table 2), which may recover the diseases related to the deficiency of vitamin C. Thiamine is a water-soluble vitamin, also called vitamin B1. It is crucial for the metabolism of glucose, and it performs a primary role in nerve, muscle, and heart function [19]. It is also used for the treatment of AIDS and elevating the immune system, such as diabetic pain. Thiamine is also used for reducing mental stress [21]. In our experiment, a small amount of vitamin B1 was found in banana fruit (unripe) and stem (Table 1). So, these two edible parts of banana can be good for recovering the deficiency of vitamin B1. Niacin is a crucial nutrient, also known as vitamin B3. Niacin helps protect skin cells from sun damage, improving joint mobility, prevents heart disease, and elevating the nervous system [22]. In our experiment, three edible parts of banana contain a small amount of niacin. Consume these consumable parts of banana in a regular diet may boost the diseases related to niacin or vitamin B3. The most common symptoms of Pyridoxine or vitamin B6 deficiency involve the digestive system and the nervous system [23]. A small amount of vitamin B6 was found in banana fruit and stem. Banana flower does not containing vitamin B6. So, consuming the banana fruit and stem in a regular diet may improve the diseases involving the deficiency of vitamin B6. Folic acid is a naturally generating vitamin B. It is the synthetic form of folate that helps make DNA and other genetic material. It is also essential for prenatal health [24]. Analysis of the folic acid of three edible parts of banana showed that banana fruit contains a high amount of folic acid compared to stem and flower.

Table 2. Profiles of water soluble vitamins of Musa paradisiaca

\begin{tabular}{cccccc}
\hline Sample name & $\begin{array}{c}\text { Ascorbic acid (vitamin C) } \\
(\mathrm{mg} / \mathrm{g})\end{array}$ & $\begin{array}{c}\text { Thiamin (vitamin B1) } \\
(\mathrm{mg} / \mathrm{g})\end{array}$ & $\begin{array}{c}\text { Niacin (vitamin B3) } \\
(\mathrm{mg} / \mathrm{g})\end{array}$ & $\begin{array}{c}\text { Pyridoxine (vitamin B6) } \\
(\mathrm{mg} / \mathrm{g})\end{array}$ & $\begin{array}{c}\text { Folic acid } \\
(\mathrm{mcg} / \mathrm{g})\end{array}$ \\
\hline Banana fruit (unripe) & $1.3 \pm 0.2$ & $0.04 \pm 0.0$ & $0.9 \pm 0.3$ & $0.3 \pm 0.0$ & $12.7 \pm 2.1$ \\
Banana stem & $1.8 \pm 0.3$ & $0.02 \pm 0.0$ & $0.7 \pm 0.4$ & $0.4 \pm 0.05$ & $5.4 \pm 0.1$ \\
Banana flower & $0.7 \pm 0.2$ & $\mathrm{NDL}$ & $0.5 \pm 0.2$ & $\mathrm{NDL}$ & $1.4 \pm 0.00$ \\
\hline
\end{tabular}

*values represent mean \pm SDs for three samples

$*$ NDL $=$ Not detected level. 


\subsection{Determination of fat-soluble vitamins}

After a quantitative analysis of fat-soluble vitamins (Table 3) of three consumable parts of banana, it was found that a good amount of vitamin A was present in three experimental parts. Vitamin D3 was not detected in any of the tested components. Only the banana flower contained a small quantity of vitamin E. Vitamin A or retinol is a fat-soluble vitamin that is naturally present in many plant and animal-based foods. Its pharmacological functions include normal vision, overall growth, stimulate reproduction, and boost the immune system. It also assists the lungs, heart, kidneys, and other organs to work properly [25, 26]. In these three edible parts (flower, fruit, and stem) of Musa paradisiaca, the right amount of vitamin A was present. Therefore, three consumable parts of Musa paradisiaca may be able to maintain the normal vision, overall growth, reproduction, heart, lungs, and kidneys functions. Vitamin E or tocopherol is a fatsoluble vitamin found in vegetable oils, cereals, meat, poultry, eggs, fruits, vegetables, and wheat germ oil. Vitamin E supplements protect cells from damage, prevent coronary heart disease, promote eye health, and support immune function [27]. In the present experiment, the banana flower also contained a little vitamin E, indicating that it could overcome the problems associated with nutritional deficiency of vitamin E.

Table 3. Profiles of fat soluble vitamins of Musa paradisiaca

\begin{tabular}{cccc}
\hline Sample name & $\begin{array}{c}\text { Retinol (vitamin A) } \\
(\mathrm{mcg} / \mathrm{g})\end{array}$ & $\begin{array}{c}\text { Cholecalciferol (vitamin D3) } \\
(\mathrm{mcg} / \mathrm{g})\end{array}$ & $\begin{array}{c}\text { Tocopherol (vitamin E) } \\
\text { (ng/g) }\end{array}$ \\
\hline Banana fruit (unripe) & $18.3 \pm 3.8$ & NDL & NDL \\
Banana stem & $11.8 \pm 2.3$ & NDL & NDL \\
Banana flower & $10.7 \pm 1.6$ & NDL & $0.3 \pm 0.0$ \\
\hline
\end{tabular}

*values represent mean \pm SDs for three samples $* \mathrm{NDL}=$ Not detected level

Literature reveals that water-soluble vitamins contained raw banana fruit were $8.70 \mathrm{mg} / 100 \mathrm{~g}$ of vitamin $\mathrm{C}, 0.031$ $\mathrm{mg} / 100 \mathrm{~g}$ of vitamin B1, $0.67 \mathrm{mg} / 100 \mathrm{~g}$ of vitamin B3, $0.36 \mathrm{mg} / 100 \mathrm{~g}$ of vitamin B6 and $20.00 \mathrm{mcg} / 100 \mathrm{~g}$ of folate, and the fat-soluble vitamins were $64.00 \mathrm{IU} / 100 \mathrm{~g}$ of vitamin $\mathrm{A}, 0.10 \mathrm{mg} / 100 \mathrm{~g}$ of vitamin $\mathrm{E}$ [28] respectively. Raw-banana flower contained $0.3 \%$ of vitamin A, 13\% of vitamin C [29]. Per 100 grams of banana flower contained $1.07 \mathrm{mg}$ of vitamin E [30]. These values are comparatively equivalent to our estimated values. Limited researches are available for vitamin estimation of banana stem. From this result, it was concluded that the geographical condition of Tripura is not affecting the vitamin content of banana.

\section{Conclusion}

Results reveal that the raw materials of Musa paradisiaca (unripe fruit, stem, and flower) collected from Tripura, India, may be used for herbal nutraceutical drug development.

\section{Conflict of interest}

The authors declare no conflict of interest.

\section{Acknowledgements}

The Indian Council of Medical Research (ICMR) (NO. 3/1/2/125/2019-(Nut.) provided financial support of this study. The authors are also grateful for the e-resources provided by Tripura University (A Central University), Suryamaninagar, Tripura, India-799022. The authors are grateful to New Jersey Feed Lab Inc., 1686 Fifth St, Trenton 
NJ 08638, USA for providing instrument facility. The authors are also grateful for Advanced State Biotech Hub, Tripura Central University-799022, for providing working facility. The authors also indebted to Mr. Waikhom Somraj Singh and Mrs. Sanchari Goswami, research scholar, Department of Pharmacy, Tripura University (A Central University), Suryamaninagar, Tripura, India-799022 for checking the scientific term of the manuscript.

\section{References}

[1] Mariotti F. Vegetarian and Plant-Based Diets in Health and Disease Prevention. Academic Press; 2017.

[2] Debnath B, Manna K. Phytochemicals and nutrient profiles, anti-oxidant activity study of three edible parts (flower, fruit and stem) of Musa paradisiaca. Current Biotechnology. 2019; 8(1): 32-41.

[3] Loganayaki N, Rajendrakumaran D, Manian S. Antioxidant capacity and phenolic content of different solvent extracts from banana (Musa paradisiaca) and mustai (Rivea hypocrateriformis). Food Science and Biotechnology. 2010; 19(5): 1251-1258.

[4] Forster M, Rodríguez Rodríguez E, Darias Martín J, Díaz Romero C. Distribution of nutrients in edible banana pulp. Food Technology and Biotechnology. 2003; 41(2): 167-171.

[5] Sidhu JS, Zafar TA. Bioactive compounds in banana fruits and their health benefits. Food Quality and Safety. 2018; 2(4): 183-188.

[6] Achilonu M, Shale K, Arthur G, Naidoo K, Mbatha M. Phytochemical benefits of agroresidues as alternative nutritive dietary resource for pig and poultry farming. Journal of Chemistry. 2018. Available from: doi: $10.1155 / 2018 / 1035071$.

[7] Kumar KS, Bhowmik D, Duraivel S, Umadevi M. Traditional and medicinal uses of banana. Journal of Pharmacognosy and Phytochemistry. 2012; 1(3): 51-63.

[8] Kalai R, Sasirekha B. Dietary guidelines to reduce the risk of renal stones. International Journal of Nursing Education and Research. 2018; 6(1): 73-77.

[9] Maleki T, Akhani H. Ethnobotanical and ethnomedicinal studies in Baluchi tribes: A case study in Mt. Taftan, southeastern Iran. Journal of Ethnopharmacology. 2018; 217: 163-177.

[10] Emmanuel MM, Didier DS. Traditional knowledge on medicinal plants use by ethnic communities in Douala, Cameroon. European Journal of Medicinal Plants. 2012; 2: 159-176.

[11] Sami R, Li Y, Qi B, Wang S, Zhang Q, Han F, Ma Y, Jing J, Jiang L. HPLC analysis of water-soluble vitamins (B2, B3, B6, B12, and C) and fat-soluble vitamins (E, K, D, A, and $\beta$-carotene) of okra (Abelmoschus esculentus). Journal of Chemistry. 2014. Available from: doi: 10.1155/2014/831357.

[12] Antakli S, Sarkees N, Sarraf T. Determination of water soluble vitamins B1, B2, B3, B6, B9, B12 and C on a C18 column with particle size $3 \mathrm{mM}$ in some manufactured food products by HPLC with UVDAD/FLD detection. International Journal of Pharmacy and Pharmaceutical Sciences. 2015; 7(6): 219-224.

[13] Kucukkolbasi S, Bilber O, Ayyildiz HF, Kara H. Simultaneous and accurate determination of water-and fat-soluble vitamins in multivitamin tablets by using an RP-HPLC method. Química Nova. 2013; 36(7): 1044-1051.

[14] Xue X, You J, He P. Simultaneous determination of five fat-soluble vitamins in feed by high-performance liquid chromatography following solid-phase extraction. Journal of Chromatographic Science. 2008; 46: 345-350.

[15] Sheng-Ji P. Ethnobotanical approaches of traditional medicine studies: Some experiences from Asia. Pharmaceutical Biology. 2001; 39: 74-79.

[16] Oguntibeju OO, Truter EJ, Esterhuyse AJ. The Role of Fruit and Vegetable Consumption in Human Health and Disease Prevention. InTech Publishers; 2013. p. 117-130.

[17] Asif M. The role of fruits, vegetables, and spices in diabetes. International Journal of Nutrition, Pharmacology, Neurological Diseases. 2011; 1(1): 27-35.

[18] Iqbal K, Khan A, Khattak MMAK. Biological significance of ascorbic acid (vitamin C) in human health-a review. Pakistan Journal of Nutrition. 2004; 3(1): 5-13.

[19] Bisika T, Courtright P, Geneau R, Kasote A, Chimombo L, Chirambo M. Self treatment of eye diseases in Malawi. African Journal of Traditional, Complementary and Alternative Medicines. 2009; 6(1): 23-29.

[20] Lonsdale D. A review of the biochemistry, metabolism and clinical benefits of thiamin (e) and its derivatives. Evidence-Based Complementary and Alternative Medicine. 2006; 3(1): 49-59.

[21] Mancinelli R, Ceccanti M. Biomarkers in alcohol misuse: their role in the prevention and detection of thiamine deficiency. Alcohol Alcoholism. 2009; 44(2): 177-182.

[22] Niacin (Vitamin B3). Available from: https://www.webmd.com/diet/supplement-guide-niacin\#1 [Accessed 24th 
February 2020].

[23] Bartel PR, Ubbink JB, Delport R, Lotz BP, Becker PJ. Vitamin B-6 supplementation and theophylline-related effects in humans. American Journal of Clinical Nutrition. 1994; 60(1): 93-99.

[24] Czeizel AE, Dudás I, Vereczkey A, Bánhidy F. Folate deficiency and folic acid supplementation: the prevention of neural-tube defects and congenital heart defects. Nutrients. 2013; 5(11): 4760-4775.

[25] Clagett-Dame M, DeLuca HF. The role of vitamin A in mammalian reproduction and embryonic development. Annual Review of Nutrition. 2002; 22(1): 347-381.

[26] Dawson MI. The importance of vitamin A in nutrition. Current Pharmaceutical Design. 2002; 6(3): 311-325.

[27] Eitenmiller RR, Lee J. Vitamin E: Food Chemistry, Composition, and Analysis. CRC Press; 2004.

[28] Banana fruit nutrition facts. Available from: https://www.nutrition-and-you.com/banana-fruit.html [Accessed 25th July 2020].

[29] Banana flower. Available from: https://www.nutritionix.com/food/banana-flower [Accessed 25th July 2020].

[30] Health benefits of banana flower. Available from: https://www.healthbenefitstimes.com/health-benefits-of-bananaflower/ [Accessed 26th July 2020]. 